\title{
Kemitraan Strategis Antar Stakeholder dalam Pengembangan Desa Wisata Gubugklakah Kabupaten Malang, Jawa Timur
}

\author{
Herlan Suherlan ${ }^{1}$, Nurdin Hidayah ${ }^{2}$, Wientor Rah Mada ${ }^{3}$, Mochammad \\ Nurrochman ${ }^{4}$, Budi Wibowo ${ }^{5}$ \\ Affiliation \\ ${ }^{1}$ Prodi Destinasi Pariwisata, Sekolah Tinggi Pariwisata (STP) Bandung; ${ }^{2}$ Prodi Manajemen \\ Destinasi Pariwisata, STP Bandung; ${ }^{3}$ Prodi Administrasi Hotel, STP Bandung; ${ }^{4}$ Prodi \\ Manajemen Tata Boga, STP Bandung; ${ }^{5}$ Prodi Manajemen Tata Hidang, STP Bandung

\section{Correspondence} \\ Herlan Suherlan. Program Studi Destinasi Pariwisata, Sekolah Tinggi Pariwisata Bandung. \\ Jl. Dr. Setiabudi No.186, Bandung, Jawa Barat 40141. Email: hel@stp-bandung.ac.id.
}

\begin{abstract}
This study intends to obtain a comprehensive information of strategic partnerships between stakeholders in the development of in the Gubugklakah Tourism Village (GBT), Malang Regency, East Java. This study uses a qualitative research design with a phenomenographic approach. Data collection was carried out by interviewing penta-helix stakeholders, observations to the potential tourism objects and how the implementation of partnership strategies there, and studying all documents related to GBT strategies and policies. The results showed that the strategy \& policy development direction of the Gubugklakah Tourism Village is to make the Tourism Village managed professionally using a business approach that involves all stakeholders in a penta-helix framework, with the goal of mutual prosperity. Stakeholder participation involved in the development of the GBT in the concept of strategic partnership has been going well which is characterized by cohesiveness based on the principle of mutual trust, openness, mutual need, and mutual benefit; The efforts made in the problem of strategic partnership are applying the five concepts of tourism village management, namely leadership, profit sharing system, product innovation, partnership, and marketing through a personal and familial approach.
\end{abstract}

Keywords: Strategic partnership; Penta-helix; Tourism village; Tourism stakeholders.

\section{Article Information}

Submitted 8 March 2020 | Accepted 3 September 2020

Recommended Citation: Suherlan, H., Hidayah, N., Mada, W. R., Nurrochman, M., Wibowo, B. (2020). Kemitraan Strategis Antar Stakeholder dalam Pengembangan Desa Wisata Gubugklakah Kabupaten Malang, Jawa Timur. Jurnal Pariwisata Terapan, 4(1), 5972. https://doi.org/10.22146/jpt.53303 


\section{Pendahuluan}

Dalam upaya mencapai target kunjungan wisata dan daya saing pariwisata, pada tahun 2017, Kementerian Pariwisata menggulirkan 3 (tiga) program utama yaitu pengembangan homestay desa wisata, pariwisata digital dan konektivitas udara. Hal tersebut seperti yang kemukakan oleh Staf Khusus Menteri Bidang Komunikasi dan Media kementerian Pariwisata, Don Kardono dalam Berdesa.Com (diakses pada 09 Januari 2020) berikut ini: "Saat ini Kementerian Pariwisata sedang menggenjot tiga program utama yakni digital tourism, homestay desa wisata dan aksesibiltas udara. Ketiga program ini digadang untuk mendukung pengembangan desa wisata yang saat ini sedang menjadi destinasi wisata yang terus diminati".

Ketua Tim Percepatan Pembangunan Destinasi Pariwisata Prioritas Hiramsyah S. Thaib dalam travel.kompas.com (diakses pada 09 Januari 2020) menegaskan bahwa alasan Kementerian Pariwisata memperioritaskan pengembangan desa wisata salah satunya adalah karena Indonesia memiliki sekitar 74.910 desa yang sangat potensial untuk dikembangkan sebagai destinasi pariwisata, disamping permintaan (demand) terhadap aktivitas desa wisata yang akhir-akhir ini semakin meningkat.

Peningkatan permintaan terhadap aktivitas desa wisata salah satunya dipicu oleh kedatangan Mantan Presiden Amerika Serikat Barack Obama yang melakukan aktivitas di beberapa desa wisata di Indonesia. "Kunjungan Obama tersebut memiliki makna yang sangat strategis, apalagi tokoh dunia itu selalu menjadi perhatian media. "Barack Obama adalah endorser strategis, tokoh dunia, salah satu pemimpin Amerika yang fenomenal. Sampai akhir masa jabatannya pun masih dipuji dan dicinta publik Amerika dan dunia," (Menteri Pariwisata, Arief Yahya dalam cnnindonesia.com, 2017 diakses pada 09 Januari 2020).

Desa wisata adalah suatu wilayah perdesaan yang menawarkan keseluruhan suasana yang mencerminkan keaslian pedesaan, arsitektur bangunan dan tata ruang desa, serta mempunyai potensi untuk dikembangkan berbagai komponen kepariwisataan, misalnya atraksi wisata makanan dan minuman, cinderamata, penginapan, dan kebutuhan lainnya (Wihasta, \& Prakoso, 2012).

Menurut Tim Percepatan Desa Wisata Kementerian Pariwisata (2017), gambaran umum kualitas desa wisata di Indonesia jika dibandingkan dengan desa wisata dari negara lain, dari sisi jumlah keragaman aktivitas sebenarnya tidak kalah dengan desa wisata dari negara lain, tetapi kelemahannya adalah dalam hal aksesibilitas, jarak tempuh yang lebih lama serta branding dan tata kelola yang belum baik. Hal tersebut menunjukkan bahwa desa wisata di Indonesia secara umum belum mampu bersaing dengan desa wisata dari negara lain.

Namun demikian, salah satu desa wisata di Indonesia yang sangat pesat perkembangannya adalah Desa Wisata Gubugklakah di Kecamatan Poncokusumo, Kabupaten Malang, terletak di lereng Gunung Bromo dan Gunung Semeru dan masuk kedalam Kawasan Pariwisata Bromo-Tengger-Semeru (BTS). Desa Wisata Ini telah memiliki segudang prestasi seperti juara I Presentasi Pokdarwis (Kelompok Sadar Wisata) se Jawa Timur pada tahun 2013, juara II lomba Pokdarwis Jawa Timur pada tahun 2013, juara III lomba Desa Wisata tingkat 
Nasional pada tahun 2014, juara I lomba Pokdarwis tingkat Nasional pada tahun 2014, dan juara I lomba Pokdarwis Jawa Timur pada tahun 2014 (Rohmah \& Ishom, 2016). Selain itu dalam RadarMalang.Id, desa wisata ini juga mendapat penghargaan Satya Lencana Kepariwisataan 2018 dari Kementerian Pariwisata.

Prestasi yang didapatkan oleh Desa Wisata Gubugklakah tersebut dapat mencerminkan betapa baiknya daya saing yang dimiliki oleh desa wisata tersebut. Menurut Hidayah (2019), daya saing sebuah destinasi pariwisata diperoleh dari tercapainya tujuan fungsi-fungsi destinasi yang salah satunya adalah fungsi koordinasi. Hidayah (2019) juga menegaskan bahwa fungsi koordinasi organisasi pengelola destinasi memiliki keluaran (output) kolaborasi yang kompak (cohesive colaboration) dari para stakeholder destinasi wisata yang memiliki sifat multi stakeholder.

Asumsi dasar dari mekanisme kolaborasi adalah hubungan kemitraan pada setiap stakeholder yang dibangun agar saling memiliki manfaat dan saling melengkapi (Suherlan, 2017). Sementara itu, kerjasama kemitraan (colaboration partnership) menurut Arifin (2011:42) dapat dipahami secara sederhana sebagai sebuah ikatan kerja sama antara personal atau organisasi sehingga menghasilkan manfaat bersama.

Atas dasar hal tersebut, maka penelitian ini bermaksud untuk mendalami bagaimana proses kemitraan strategis antar stakeholder dalam pengembangan Desa Wisata di Desa Gubugklakah Kawasan Wisata BTS Kab. Malang, untuk dijadikan sebagai informasi patok banding (benchmark) terhadap desa wisata yang belum maju di Indonesia. Sementara itu peneliti menetapkan 3 (tiga) pertanyaan penilitian yaitu: 1) Bagaimana arah strategi dan kebijakan pengembangan Desa Wisata Gubugklakah berbasis stakeholder?; 2) Bagaimana peran stakeholder dalam pengembangan Desa Wisata Gubugklakah?; dan 3) Bagaimana permasalahan serta upaya-upaya yang dilakukan para stakeholder dalam pengembangan desa wisata Gubugklakah?.

\section{Literature Review \\ Desa Wisata}

Desa wisata adalah suatu bentuk integrasi antara atraksi, akomodasi dan fasilitas pendukung yang disajikan dalam suatu struktur kehidupan masyarakat yang menyatu dengan tata cara dan tradisi yang berlaku (Wiendu, 1993). Sedangkan Inskeep (1991), mendefinisikan Desa Wisata sebagai: "where small groups of tourists stay in or near traditional, often remote villages and learn about village life and the local environment." Hal tersebut dapat diartikan bahwa desa wisata merupakan tempat dimana sekelompok kecil wisatawan tinggal dalam atau dekat dengan suasana tradisional, sering di desa-desa yang terpencil dan belajar tentang kehidupan pedesaan dan lingkungan setempat.

\section{Stakeholder Desa Wisata}

Hal tersebut dapat diartikan bahwa desa wisata merupakan tempat dimana sekelompok kecil wisatawan tinggal dalam atau dekat dengan suasana tradisional, sering di desa-desa yang terpencil dan belajar tentang kehidupan pedesaan dan lingkungan setempat. Menurut Hidayah (2019), dalam pengembangan destinasi pariwisata diperlukan kolaborasi antar stakeholder yang cohesive (kompak). Sementara, pendekatan pihak-pihak yang terlibat dalam stakeholder pariwisata yang diacu oleh Kementerian Pariwisata Indonesia mengusung 
konsep model penta helix. Secara Bahasa, penta berarti 5 (lima) dan helix berarti sinergi. Jadi secara Bahasa dapat disimpulkan bahwa penta helix adalah sinergi dari lima pihak atau aktor yang saling berkolaborasi. Model penta helix ini merupakan pengembangan dari model triple helix dan quadruple helix yang sebelumnya telah berkembang dalam konsep pembangunan kreatifitas sumber daya manusia suatu daerah. Menurut Lindmark, Sturesson \& Roos (2009) dalam Muhyi dkk. (2017), "Penta helix is an extension of the triple helix strategy by involving various elements of the community or non-profit institutions in order to realize the innovation. Through synergistic collaboration it is expected to realize an innovation that is supported by a variety of resources that interact synergistically." Penta helix berisi lima pihak yang saling bersinerg yaitu akademisi, industri (swasta) pemerintah, masyarakat lokal dan media. Pengembangan model yang holistik, dan kolaborasi terintegrasi antar kelima pihak tersebut diadaptasi dari Boras, 2013., Calzada \& Bjork, 2013; Nanotechnology, 2012; Noorul, 201; Sugiama, 2016).

\section{Kemitraan Strategis}

Kemitraan, menurut Webster's Dictionary, merupakan sebuah hubungan yang dibangun oleh salah satu pihak terhadap pihak lainnya yang memiliki karakteristik khusus yang dibutuhkan oleh pihak lainnya dan biasanya melibatkan kerja sama yang erat antara dan tanggung jawab bersama. Sementra itu, kerjasama kemitraan (colaboration partnership) menurut Arifin (2011: 42) dapat dipahami secara sederhana sebagai sebuah ikatan kerja sama antara personal atau organisasi sehingga menghasilkan manfaat bersama. Komponen penting dari sebuah kerjasama kemitraan (colaboration partnership) dengan masyarakat agar berhasil dengan baik adalah tim yang bertanggung jawab, komitmen setiap stakeholder dan tujuan bersama yang hendak dicapai (Wise, et al, 2005).

Kemitraan Strategis didefinisikan sebagai usaha bersama yang saling menguntungkan antara satu atau lebih agen organisasi dan satu atau lebih pemasok, yang (1) menghasilkan komoditas atau layanan yang tidak tersedia dalam bentuk yang ada, dan / atau (2) menghasilkan berbagi keahlian, sumber daya, layanan atau komoditas di antara orgainisasi. Pemasok dapat mencakup tidak hanya vendor sektor swasta, tetapi juga entitas sektor publik seperti kota, negara lain, atau pemerintah pusat (NYS Procurement Bulletin, 1996).

Kemitraan strategis lebih mengarah ke bentuk kemitraan atau aliansi antara organisasi nirlaba dan organisasi non-pemerintah (Arya dan Salk, 2006). Kemitraan strategis mencakup berbagai jenis kemitraan mulai dari keterlibatan rendah, hubungan pendanaan hingga keterlibatan tinggi, usaha patungan ekuitas. Dalam jenis kemitraan ini, mitra bekerja bersama secara strategis "pada masalah bersama yang ingin mereka selesaikan" (Neergaard dkk., 2009). Usaha semacam itu menciptakan hubungan yang jauh lebih tergantung antara mitra, dan "nilai hanya akan diciptakan melalui pertukaran ide, sumber daya, dan upaya yang saling bergantung" (Googins dan Rochlin, 2000). Dalam kemitraan ini, para mitra melihat masalah-masalah sulit yang memengaruhi kedua misi mereka, dan tidak dalam posisi untuk menyelesaikan berbagai hal sendiri. Dengan demikian mereka dituntut untuk berkolaborasi agar berhasil. Kemitraan strategis, menurut teori kemitraan, yang paling potensial untuk nilai tambah, karena kekuatan gabungan memungkinkan para aktor untuk mencapai hasil yang tidak dapat dicapai oleh kedua pasangan itu secara sendiri-sendiri (Neergaard dkk., 2009). 


\section{Metode}

Penelitian ini menggunakan disain penelitian kualitatif dengan pendekatan fenomenografi yang berusaha memahami sudut pandang, pemikiran, pengalaman para stakeholder mengenai kemitraan strategis dalam upaya mengembangkan Desa Gubugklakah sebagai desa wisata yang memiliki daya saing pariwisata.

Disain penelitian dilakukan dalam lima langkah sebagaimana yang telah kemukakan oleh Denzin dan Lincoln (1998), yaitu, 1) menempatkan bidang penelitian dengan menggunakan pendekatan kualitatif, 2) pemilihan paradigma teoritis yakni eksploratif untuk menggali lebih dalam tentang kemitraan strategis yang dilakukan oleh pengelola Desa Wisata Gubugklakah, 3) menghubungkan paradigma penelitian yang dipilih dengan dunia empiris lewat metodologi, 4) pemilihan metode pengumpulan data, dan 5) pemilihan metode analisis data.

Untuk mencapai tujuan akhir kegiatan berupa diperolehnya informasi yang komprehensif tentang kemitraan strategis yang dilakukan oleh pengelola Desa Wisata Gubugklakah dalam mendukung kepariwisataan di Kawasan BTS, dilakukan dengan 3 (tiga) tahapan, yakni: (1) tahap pra lapangan; (2) tahap lapangan (field research); dan (3) tahap pasca lapangan. Wawancara mendalam dilaksanakan dengan cara mengajak para informan untuk berbicara bebas dan mendalam menyangkut arah strategi dan kebijakan pengembangan Desa Wisata Gubugklakah; potensi pariwisata Desa Gubugklakah; peran masing-masing stakeholder dalam pengembangan Desa Wisata Gubugklakah. Selain itu, peneliti juga akan melakukan observasi untuk melihat bagaimana kondisi di lapangan Desa Wisata Gubugklakah dalam memanfaatkan potensi wisata dan melakukan strategi kemitraan bersama stakeholder. Hasil observasi tersebut sangat berguna untuk mengkonfirmasi atau sebagai data triangulasi terhadap hasil wawancara mendalam yang sudah dilakukan. Studi dokumen juga akan dilakukan dengan mengkaji berbagai dokumen yang relevan dan dibutuhkan dalam penelitian, antara lain meliputi, (1) Peraturan dan Perundang-undangan; (2) Strategi dan Kebijakan Desa Wisata Gubugklakah, serta dokumen-dokumen baik cetak maupun elektronik menyangkut pengelolaan dan pengembangan Desa Wisata Gubugklakah.

Analisis data dilakukan melalui tahapan pengkodean, kategorisasi, reduksi, dan display data. Sementara itu untuk menjaga keabsahan atau kepercayaan (validity) temuan penelitian dilakukan melalui teknik triangulasi yaitu dengan menggunakan triangulasi sumber data dan triangulasi metode.

\section{Hasil dan Pembahasan}

\section{Arah Strategi dan Kebijakan Pengembangan Desa Wisata Gubugklakah Berbasis Stakeholder}

Ketua Lembaga Desa Wisata (Ladesta) Gubugklakah (informan 1) menerangkan sejarah terbentuknya Desa Wisata Gubugklakah berawal dari keprihatinan masyarakat setempat yang hanya mendapatkan debu dan kebisingan dari orang-orang yang berwisata ke Bromo. Masyarakat pada waktu itu tidak mendapatkan suatu apapun dari kegiatan pariwisata. Sehingga pada tahun 2010 masyarakat mulai mencetuskan untuk mendirikan Kelompok Sadar Wisata (Pokdarwis) sekaligus membentuk Lembaga Desa Wisata yang disebut dengan Ladesta. Ladesta itu sendiri dibentuk sebagai lembaga usaha, karena Pokdarwis menurut 
Ketua Ladesta tidak bicara uang, hanya sebagai penggerak atau motivator. Sedangkan Ladesta bisa menjual desanya seperti paket-paket wisata.

Ketua Pokja Homestay Gubugklakah (informan 2) menegaskan bahwa seiring waktu berjalan, tepatnya pada tanggal 20 Agustus 2010 para penggagas berkumpul di Balai Desa untuk mendirikan Ladesta, yang dibantu oleh para mahasiswa KKN dari UGM. Dia menegaskan bahwa setelah Ladesta terbentuk, para pengurus masih kebingunan untuk menjalankan roda organisasi Ladesta ini. Mereka masih belum memahami bagaimana tugas dan fungsi dari Ladesta tersebut. Sementara waktu itu belum ada bimbingan dari dinas terkait satupun. Oleh karena itu para pengurus berinisiatif untuk belajar secara otodidak. Para pengurus banyak belajar di luar tentang agro apel, tetapi tidak langsung dengan pengelolanya tetapi melihat dari kejauhan. Informan 2 sendiri mencoba untuk belajar menganai Desa Wisata ke Pentingsari di Jogja, seperti pernyataannya: "Terus saya juga ketika ada tugas dari sekolahan untuk ke Jogja, saya sempatkan untuk mampir ke Desa Penting Sari, untuk melihat sama temen-temen guru waktu itu ada kumpulan guru-guru IPS se Indonesia di saat itu dari di bawah naungan SBP (Sekolah Berbasis Pesantren) ke sana ke Penting Sari main-main. Yang lain bermain-main di sana, saya malah ketemu ketuanya si Pa Toto untuk melihat Homestay, ooo hanya seperti ini saja homestay tu, kalau gitu kita juga bisa. Ternyata homestay itu rumah tinggal yang salah satu kamarnya disewakan".

Dengan demikian terlihat bahwa hal esensial dari pemaparan informan 1 dan 2 tentang arah strategi dan kebijakan pengembangan Desa Wisata Gubugklakah berbasis stakeholder, bahwa Ladesta terbentuk karena keprihatinan; Ladesta dibentuk bertujuan untuk mensejahterakan masyarakat melalui pariwisata; ladesta dibentuk untuk mengelola Desa Wisata secara bisnis/usaha dan arah kebijakan Desa Wisata Gubugklakah yaitu melibatkan semua pihak yang berkepenttingan dalam membangun Desa Wisata Gubugklakah.

Senada dengan apa yang disampaikan oleh informan 1 dan informan 2, Ketua Pokja Pemasaran Ladesta (informan 3) mengemukakan bahwa pada awalnya, tujuan awal pembentukan desa wisata Gubugklakah adalah untuk kegiatan sosial. Pada tahun 2008, anak2 muda desa Gubugklakah berkumpul untuk melakukan penggalangan dana. Mayoritas pemuda desa Gubugklakah yang sehari-hari bekerja sebagai buruh tani. Pagi-pagi pergi ke kebun, siang cari curi kayu bakar di hutan. Sehari mereka bekerja mulai dari jam 7 sampai jam 12, dan dibayar Rp6.000/hari. Jadi dapat dikatakan bahwa latar belakang dibentuknya desa wisata adalah adanya keinginan untuk meningkatkan kesejahteraan masyarakat desa.

Sementara itu menurut Informan 3, program jangka panjang Desa Wisata gubugklakah adalah mendatangkan wisatawan mancanegara. Mereka menargetkan bahwa tahun 2025 desa wisata Gubugklakah siap menerima kunjungan wisatawan mancanegara. Saat ini mereka belum siap untuk mendatangkan wisatawan dari luar negeri, meskipun sudah banyak wisatawan dari luar negeri yang mau kontrak dengan mereka. Mereka belum siap dengan SDM yang mereka miliki, terutama kemampuan bahasa inggris, kesiapan homestay yang memenuhi standar mereka, sehingga akan betah dan tinggal cukup lama di Gubugklakah. Dari ketiga informan tersebut maka diperoleh data Axial Coding dalam Tabel 1 berikut: 
Tabel 1. Arah Strategi dan Kebijakan Pengembangan Desa Wisata Gubugklakah Berbasis Stakeholder

\begin{tabular}{|c|c|c|c|c|}
\hline \multirow[t]{2}{*}{ No. } & \multirow[t]{2}{*}{ Topik } & \multicolumn{3}{|c|}{ Perspektif } \\
\hline & & Informan 1 & Informan 2 & Informan 3 \\
\hline 1 & $\begin{array}{l}\text { Latar belakang } \\
\text { terbentuknya Desa } \\
\text { Wisata }\end{array}$ & $\begin{array}{l}\text { - Keprihatinan } \\
\text { - Mensejahterakan } \\
\text { masyarakat } \\
\text { - Kegiatan bisnis } \\
\text { - Melibatkan semua } \\
\text { pihak }\end{array}$ & $\begin{array}{l}\text { - Keprihatinan } \\
\text { - Mensejahterakan } \\
\text { masyarakat } \\
\text { - Kegiatan bisnis } \\
\text { - Melibatkan semua } \\
\text { pihak }\end{array}$ & $\begin{array}{l}\text { - Kesejanteraan } \\
\text { masyarakat } \\
\text { - Kesejahteraan } \\
\text { sosial }\end{array}$ \\
\hline 2 & $\begin{array}{l}\text { Formalitas bentuk } \\
\text { pengelolaan Desa } \\
\text { Wisata }\end{array}$ & $\begin{array}{l}\text { - Surat Keputusan } \\
\text { Kepala Desa } \\
\text { - Surat Keputusan } \\
\text { Kepala Dinas } \\
\text { Pariwisata } \\
\text { - Struktur organisasi } \\
\text { Desa Wisata }\end{array}$ & $\begin{array}{l}\text { - Surat Keputusan } \\
\text { dari pemerintah } \\
\text { - Struktur organisasi } \\
\text { Desa Wisata }\end{array}$ & $\begin{array}{l}\text { - Struktur } \\
\text { organisasi Desa } \\
\text { Wisata } \\
\text { - Standar } \\
\text { operating } \\
\text { prosedure }\end{array}$ \\
\hline 3 & $\begin{array}{l}\text { Strategi kemitraan } \\
\text { yang dikembangkan }\end{array}$ & $\begin{array}{l}\text { - Sinergi Internal } \\
\text { - Sinergi Eksternal } \\
\text { - Go Digital } \\
\text { Payung Hukum Desa } \\
\text { Wisata } \\
\text { - Bumdes } \\
\text { - Akses Permodalan }\end{array}$ & $\begin{array}{l}\text { - Sinergi Internal dan } \\
\text { eksternal } \\
\text { - Digitalisasi } \\
\text { - Payung Hukum } \\
\text { - Bumdes } \\
\text { - Sumber } \\
\text { Permodalan }\end{array}$ & $\begin{array}{l}\text { - } \text { Belajar dari } \\
\text { orang lain } \\
\text { - Pemanfaatan IT } \\
\text { - Pentingnya } \\
\text { promosi } \\
\text { - Pentingnya } \\
\text { travel agent }\end{array}$ \\
\hline
\end{tabular}

(Sumber: Axial Data Coding, 2019)

\section{Peran Stakeholder Dalam Pengembangan Desa Wisata Gubugklakah}

Desa Wisata Gubuklakah melakukan kerjasama atau kemitraan dengan unsur Penta-Helix yaitu dengan pemerintah, akademisi, asosiasi atau paguyuban, swasta dan masyarakat. Untuk kerjasama dengan pemerintah dilakukan dengan semua tingkatan pemerintah seperti Desa, Kecamatan, Kabupaten sampai ke pusat (Ketua Ladesta, informan 1). Dia menegaskan bahwa kalau bicara kerjasama dengan pemerintah yang terlibat bukan hanya dari Dinas saja, tetapi dengan semua unsur kedinasan yang ada. Seperti mengenai penataan Sapta Pesona ketiga tentang hijau (green) Gubugklakah bekerjasama dengan dinas lingkungan hidup, untuk minta bibit dengan dinas pertanian dan. Terus untuk kesehatan gubugklakah bekerjasama dengan Dinas Kesehatan. Selanjutnya untuk rambu-rambu gubugklakah bekerjasama dengan dinas perhubungan, dengan PU serta Cipta Karya untuk jalan. Secara teknis kerjasama tersebut dilakukan tidak secara langsung tetapi Ladesta meminta kepada Desa, selanjutnya Desa yang menindaklanjuti ke unsur-unsur pemerintah tersebut diatas. Untuk bantuan sendiri, Gubugklakah baru sekali mendapat bantuan dari PMPN Mandiri pariwisata yaitu mendapatkan bantuan senilai 70 juta pada tahun 2013. Dan mungkin karena Gubuklakah terlanjur sudah mandiri tanpa bantuan pemerintahpun sebenarnya sudah bisa jalan. Untuk kerjasama dengan akademisi, Ketua Ladesta menjelaskan bahwa kerjasama dilakukan dengan program Kuliah Kerja Nyata (KKN) dengan Pendidikan tinggi. Kerjasamanya lebih bersifat bantuan seperti untuk dimintai membereskan administrasi di desa, pemberdayaan masyarakat dan Sharing ilmu dengan masyarakat atau pelatihan- 
pelatihan. Untuk kerjasama dengan asosiasi atau paguyuban, informan 1 dan informan 2 menerangkan kerjasama dengan pokdarwis, HPI, PHRI, Paguyuban Jeep, dll. Sementara itu kerjasama kerjasama dengan pihak swasta dilakukan dengan biro perjalanan yang saat ini sudah bekerjasama dengan lebih dari 100 biro perjalanan yang kebanyakan berasal dari Jabodetabek. Biro perjalanan tersebut membawa tamu pelajar, mahasiswa untuk edukasi menggunakan minibus. Jadi Ladesta yang menyusun paketnya, pihak biro perjalanan yang menjualnya. Dan terakhir Ketua Ladesta menjelaskan kerjasama dengan masyarakat melalui pemilik homestay, pemilik jeep, pemilik perkebunan apel dll.

Menurut informan 2, bentuk kerjasama dilakukan yaitu dengan dasar kepercayaan, tidak menggunakan bentuk formal seperti surat perjanjian atau kontrak. Namun yang paling ditekankan adalah bahwa Desa Wisata itu harus satu pintu. Ketua Ladesta juga menegaskan bahwa kerjasama yang dilakukan dengan asas saling percaya tersebut sampai saat ini masih berhasil karena sebenarnya kami saling membutuhkan dan saling mendukung.

Sistem pembayaran dilakukan secara cash atau langsung ketika ada tamu datang, informan 2 mencontohkan sistem pembayaran sebagai berikut: "Misalnya Bapak ke sini rombongan 10 orang nanti diinformasikan ke tim pemasaran Ladesta ada tamu dari saya 10 orang, selanjutnya tim pemasaran ngomong ke divisi homestay, pemandu, dan transportasi bahwa ada tamu 10 orang selanjutnya ketua pokja tersebut mencatat dan memberikan rekomendasi homestay, transportasi dan pemandu yang mana yang akan mendapat giliran melayani. Pembayaran diberikan kepada penyedia jasa secara langsung pada saat itu juga oleh Ladesta dengan cara mengambil dulu margin atau untung untuk operasional pengelolaan seperti honor pengurus yang bekerja, uang kas dan dana pengembangan".

Gambaran lengkap pengelolaan desa wisata Gubugklakah tergambar dalam struktur organisasi Ladesta. Dari struktur terlihat bahwa secara struktural, ketua Ladesta bertanggung jawab langsung kepada Kepala Desa sebagai pelindung. Organisasi ini cukup ramping, terdiri dari unsur pimpinan (ketua dan wakil ketua), sekretaris \& bendahara, selebihnya adalah kelompok-kelompok kerja (informan 3). Menurut informan 3 , semua yang ada dalam struktur, bekerja sesuai dengan SOP. Dalam perjalanannya, Ladesta sulit berkembang, karena sulit mendapatkan bantuan dana dari pihak luar. Oleh karena itu, pada tahun 2018 dibentuk Badan Usaha Milik Desa (BUMDES), dengan harapan dapat melakukan pencarian dana dan mengelolanya secara mandiri. Baru tahun 2019, Ladesta mau dimasukkan ke unit Bumdes. Sistem pberian gaji/honor di Ladesta, yang kerja yang dapat bayaran. Mereka sepakat siapapun yang bekerja, yang terjun ke lapangan itu yang diberi bayaran. Dari informan-informan tersebut maka diperoleh data Axial Coding dalam Tabel 2 berikut: 
Tabel 2. Peran Stakeholder Dalam Pengembangan Desa Wisata Gubugklakah

\begin{tabular}{|c|c|c|c|c|}
\hline \multirow[t]{2}{*}{ No. } & \multirow[t]{2}{*}{ Topik } & \multicolumn{3}{|c|}{ Perspektif } \\
\hline & & Informan 1 & Informan 2 & Informan 3 \\
\hline 1 & $\begin{array}{l}\text { Pihak yang diajak } \\
\text { kerjasama }\end{array}$ & $\begin{array}{l}\text { - Pemerintah } \\
\text { - Akademisi } \\
\text { - Asosiasi atau } \\
\text { Paguyuban } \\
\text { - Swasta } \\
\text { - Masyarakat }\end{array}$ & $\begin{array}{l}\text { - Pemerintah } \\
\text { Perguruan Tinggi } \\
\text { - Asosiasi } \\
\text { - Swasta } \\
\text { - Masyarakat }\end{array}$ & $\begin{array}{l}\text { - Travel } \\
\text { - Sekolah-sekolah } \\
\text { - Masyarakat }\end{array}$ \\
\hline 2 & $\begin{array}{l}\text { Bentuk kerjasama } \\
\text { yang dilakukan } \\
\text { dengan pemasok }\end{array}$ & $\begin{array}{l}\text { - Kerjasama non- } \\
\text { formal } \\
\text { - Asas saling percaya } \\
\text { - Saling } \\
\text { menguntungkan }\end{array}$ & $\begin{array}{l}\text { - Kerjasama informal } \\
\text { - Saling percaya } \\
\text { - Saling } \\
\text { membutuhkan }\end{array}$ & $\begin{array}{l}\text { - Kekeluargaan } \\
\text { - Secara informal } \\
\text { - Keterbukaan }\end{array}$ \\
\hline 3 & Sistem pembayaran & $\begin{array}{l}\text { - Pembayaran secara } \\
\text { cash }\end{array}$ & $\begin{array}{l}\text { - Pembayaran secara } \\
\text { cash }\end{array}$ & $\begin{array}{l}\text { - Langsung } \\
\text { - Kadang-kadang } \\
\text { dengan DP }\end{array}$ \\
\hline
\end{tabular}

(Sumber: Axial Data Coding, 2019)

\section{Permasalahan \& Upaya-Upaya yang Dilakukan Para Stakeholder dalam Pengembangan Desa Wisata Gubugklakah}

Ketua Ladesta (informan 1) menjelaskan bahwa dalam pengelolaan Desa Wisata Gubugklakah sering terjadi permasalahan dan yang paling banyak adalah dalam masalah keuangan, yaitu biasanya kecemburuan. Jika terdapat masalah seperti itu, biasanya pengurus langsung berkumpul pada hari itu juga dan harus selesai pada saat itu juga. Jadi kalau ada masalah pada pagi hari atau siang hari, pada malam hari pengurus dikumpulkan agar masalah tidak berlarut-larut. Ketua Ladesta mengungkapkan bahwa pernah juga ada asbak yang melayang gara-gara hanya ada masalah uang lima ribu tetapi setelah itu masalah selesai dan kembali normal lagi. Masalah-masalah menganai hal tersebut sering terjadi waktu dulu sekitar tahun 2013 tetapi kalau sekarang sudah tidak ada.

Lebih lanjut, ketua paguyuban home stay (informan 2) menjelaskan bahwa cara untuk menanggapi stigma negatif mengenai pariwisata adalah dengan bersabar dan terus bersosialisasi, seperti yang dikatakannya: "Kami memberikan jawaban kepada pihak-pihak yang berfikir negatif tersebut bukan dengan ucapan tetapi dengan bukti. Dan Alhamdulillah dulu yang pernah mencibir kami, sekarang sudah bergabung dan bahkan rumahnya sendiri sudah dijadikan homestay. Dan dulu yang memusuhi kami secara terang-terangan sekarang menjadi penyedia transportasi untuk menjemput tamu".

Informan 1 mengungkapkan bahwa kunci sukses dari Ladesta Gubugklakah selama ini yaitu dengan menerapkan 5 konsep yang dianut oleh Ladesta. Pertama yaitu masalah kepemimpinan, Jadi seorang pemimpin itu harus bisa mendelegasikan pekerjaan kepada anggota, jadi tidak semua ditangani oleh satu orang bukan one man show, tetapi semua harus terlibat, baik mulai dari pimpinan sampai anggota tugasnya harus ada sendiri-sendiri. Yang kedua yaitu sistem pembagian profit, jadi kalau ketua tidak terlibat dalam melayani tamu maka Ladesta tidak menganggarkan untuk itu. Contohnya Ketua Ladesta tidak terlibat mulai dari awal, tidak ikut menyambut dan sebagainya, satu rupiahpun beliau tidak berhak. Jadi sistemnya yaitu siapa yang bekerja, dia yang mendapatkan uang. Yang ketiga yang dilakukan adalah selalu menggunakan perencanaann dan penelitian untuk melakukan 
inovasi produk. Jadi Ladesta selalu melakukan identifikasi potensi dan identifikasi permasalahan. Contohnya dulu di Gubugklakah ini hanya memiliki daya tarik wisata Coban Pelangi dan Bromo, kemudian di sini ada potensi untuk rafting dan ada operator dari luar yang ingin menyediakan jasa rafting, kemudian kami bekerjasama dengan Perhutani. Jadi Ladesta yang memasarkan rafting dan operator tersebut yang mengoperasionalkan wisata rafting-nya. Jadi gubugklakah memiliki prinsip "one village multi product" tidak "one village one product", agar banyak pilihan dan tidak membosankan, sehingga Gubugklakah harus melakukan inovasi terus menerus dan terakhir Gubugklakah sudah memiliki 14 paket edukasi yandihasilkan dari inovasi produk tersebut. Yang ke-empat adalah melakukan kemitraan dengan seluruh pihak-pihak yang berkepentingan (stakeholders). Dan yang kelima adalah pemasaran. Untuk pemasaran, disamping Ladesta bekerjasama dengan biro perjalanan, Ladesta juga memberikan kebebasan kepada semua anggota untuk memasarkan, tapi jangan sampai posting harga di media sosial, karena Ladesta menjaga kode etik dengan Biro Perjalanan. Selanjutnya Ladesta juga selalu menjaga etika bahwa siapapun yang mendapatkan tamu, masuknya tetap harus satu pintu yaitu melewati Pokja Pemasaran Ladesta.

Karena Ladesta tidak ingin seperti homestay yang ada di daerah lain, yang bebas memasarkan dan mencari sendiri tamu masing-masing, yang akhirnya banyak homestay yang mati. Selanjutnya adalah Ladesta menerapkan pemasaran kerjasama yang tidak menganggap yang lain itu pesaing sehingga saling melengkapi. Contohnya tamu yang ingin ke pantai, Ladesta arahkan ke pokdarwis yang memiliki daya tarik pantai dan sebaliknya pokdarwis yang ada di luar merekomendasikan Coban Pelangi yang ada di Gubugklakah jika tamu mencari air terjun. Bahkan Ladesta memiliki paket bersama dengan Pokdarwis atau Desa Wisata yang lainnya yaitu paket empat hari tiga malam, mulai dari Pujon Kidul sampai laut selatan dan terakhir di Bromo. Untuk pengetahuan bahwa Di Malang ini memiliki 160 Pokdarwis dan 18 Desa Wisata, dan Ladesta bekerjasama pemasaran dengan mereka itu (informan 2).

Sementara itu, informan 3 mengatakan bahwa kendala utama yang sering dihadapi adalah masalah keuangan dan harapan masyarakat yang menginginkan hasil yang instan. Menurutnya, Kalau menyangkut SDM, desa Gubugklakah merasa sudah cukup memiliki kapabilitas, karena banyak dibantu oleh banyak pihak, mulai dari dinas, para volenteer. Sekarang masyarakat rata-rata sudah bisa foto, editing video. Di desa ini mulai dari penari, lighting, sound system, dan semua dokumentasi dibuat oleh tim mereka yang anak-anak rata-rata masih di SD, SMP, dan SMA.

Menurut informan 3, strategi marketing yang dilakukan oleh Ladesta lebih banyak menggunakan Instagram. Mereka banyak melalukan follow sebanyak-banyaknya kepada sekolah dan travel. Dari situ mereka DM paket-paket yang ada di desa Gubugklakah. Semua anggota pokja Ladesta semuanya merupakan marketing. Mereka memiliki keyakinan bahwa semua desa bisa dijadikan destinasi wisata, yang penting para pemuda dan pemangku di desanya memiliki kemauan, harus mau berproses mulai dari nol, mau belajar.

Prinsip kemitraan menurut informan 3 adalah belajar dan saling memberi. Jika ada desa lain berkembang, kemudian kita anggap sebagai saingan, bagi mereka adalah kebodohan. Kalau desa-desa tetangga belum maju, mereka ke sini untuk belajar. Desa-desa wisata laindi luar 
desa mereka partner, bukan saingan. Jadi apa yang nggak ada di desa lain, mereka bantu jual dan sebaliknya, apa yang ada di Gubugklakah, itu yang mereka jual. Sebagai contoh misalnya Desa Wringin Anom dengan Desa Gubugklakah adalah dua desa yang berdampingan. Jika mereka iri kepada desa yang sudah berkembang, itu adalah suatu kebodohan. Tapi kalau mereka saling bermitra, hasilnya lebih besar dan menguntungkan. Menurut informan 3, jika warga desa sudah makmur semuanya, doanya itu untuk mereka sendiri. Mereka punya prinsip bahwa bersaing merupakan hal yang biasa, tapi partner itu penting. Misalnya ketika desa wisata Gubugklakah butuh bus, pasti mereka akan mencari ke kota. Ketika mereka ada masalah di kota, mereka pasti butuh bantuan dari rekan-rekan di kota. Termasuk di Dieng, Jakarta, Jambi di mana pun mereka berada, selalu berkoordinasi. Mereka bekerjasama dengan banyak desa, misalnya dengan desa Ngadas sampai Dieng Wonosobo, mereka sudah seperti keluarga. Kalau bentuk kerjasama dengan Perhutani mereka melakukannya secara informal dan kekeluargaan. Dalam kontek pariwisata seperti itu pasti sudah berlaku seperti itu.

Dalam melakukan kerjasama dengan pihak lain, prinsip yang harus didahulukan adalah keterbukaan, seperti keluarga. Mulai dari awal jangan sampai ada yang mengganjal di belakang. Kalau ada masalah, mereka tuntaskan segera, tidak dibiarkan berlarut-larut. Menurut informan 3, dalam segi permasalahan, mereka selalu membahas bahwasanya dalam sekitar masalah, tidak ada yang salah tidak ada yang benar, tapi setiap masalah adalah untuk mengembangkan mereka untuk mencari solusi dan bagaimana mereka berkembang. Yang paling penting adalah mengantisipasi jangan sampai ada masalah di kemudian hari, dengan membuat alur kerja. Jadi intinya, masalah itu diciptakan untuk membuat mereka lebih besar. Dari informan-informan tersebut maka diperoleh data Axial Coding dalam Tabel 3 berikut:

Tabel 4.3. Permasalahan \& Upaya-Upaya Yang Dilakukan Para Stakeholder Dalam Pengembangan Desa Wisata Gubugklakah

\begin{tabular}{|c|c|c|c|c|}
\hline \multirow[t]{2}{*}{ No. } & \multirow[t]{2}{*}{ Topik } & \multicolumn{3}{|c|}{ Perspektif } \\
\hline & & Informan 1 & Informan 2 & Informan 3 \\
\hline 1 & $\begin{array}{l}\text { Masalah yang } \\
\text { dialami } \\
\text { dalam } \\
\text { pengelolaan } \\
\text { Desa Wisata }\end{array}$ & $\begin{array}{l}\text { - Masalah keuangan } \\
\text { - Tidak melama-lamakan } \\
\text { masalah } \\
\text { - Dianggap sebagai orang } \\
\text { gila } \\
\text { - Stigma negatif mengenai } \\
\text { pariwisata }\end{array}$ & $\begin{array}{l}\text { - Masalah keuangan } \\
\text { - Sering terjadi di } \\
\text { tahun-tahun awal } \\
\text { - Citra yang buruk } \\
\text { tentang pariwisata }\end{array}$ & $\begin{array}{l}\text { - Keterbatasan } \\
\text { anggaran } \\
\text { - Kemampuan } \\
\text { bahasa inggris }\end{array}$ \\
\hline 2 & $\begin{array}{l}\text { Upaya yang } \\
\text { dilakukan }\end{array}$ & $\begin{array}{l}\text { - Bersabar dan terus } \\
\text { bersosialisasi } \\
\text { - Memberikan bukti bukan } \\
\text { dengan kata-kata } \\
\text { - Bermitra }\end{array}$ & $\begin{array}{l}\text { - Bersabar } \\
\text { - Bersosialisasi } \\
\text { - Bekerja sacara nyata } \\
\text { - Bekerjasama dengan } \\
\text { stakeholder }\end{array}$ & $\begin{array}{l}\text { - Berusaha } \\
\text { profesional } \\
\text { - Terus belajar } \\
\text { - Studi banding }\end{array}$ \\
\hline 3 & $\begin{array}{l}\text { Kunci sukses } \\
\text { menjadi Desa } \\
\text { Wisata } \\
\text { terbaik }\end{array}$ & $\begin{array}{l}\text { - Lima konsep pengelolaan } \\
\text { Desa Wisata } \\
\text { - Kepemimpinan } \\
\text { - Sistem Pembagian Profit } \\
\text { - Inovasi Produk } \\
\text { - Kemitraan } \\
\text { - Pemasaran }\end{array}$ & $\begin{array}{l}\text { - Kepemimpinan } \\
\text { - Sistem Pembagian } \\
\text { keuntungan } \\
\text { - Inovasi Produk } \\
\text { - Kerjasama dengan } \\
\text { pihak lain } \\
\text { - Marketing }\end{array}$ & $\begin{array}{l}\text { - Optimalisasi } \\
\text { SOSMED } \\
\text { - Semua anggota } \\
\text { organisasi sebagai } \\
\text { pemasar } \\
\text { - Kemauan untuk } \\
\text { terus belajar }\end{array}$ \\
\hline
\end{tabular}




\begin{tabular}{|c|c|c|c|c|}
\hline 4 & $\begin{array}{l}\text { Cara } \\
\text { mengompaka } \\
\text { n lembaga }\end{array}$ & $\begin{array}{l}\text { - Menanamkan kesadaran } \\
\text { kepada pentingnya } \\
\text { ladesta } \\
\text { - Tidak menunda-nunda } \\
\text { permasalahan yang } \\
\text { muncul } \\
\text { - Pendekatan personal dan } \\
\text { kekeluargaan }\end{array}$ & $\begin{array}{l}\text { - Memberikan } \\
\text { kesadaran kepada } \\
\text { masyarakat } \\
\text { - Pendekatan personal } \\
\text { - Kekeluargaan }\end{array}$ & $\begin{array}{l}\text { - Keterbukaan } \\
\text { - Pentingnya } \\
\text { problem solving } \\
\text { - Membuat SOP }\end{array}$ \\
\hline 5 & $\begin{array}{l}\text { Strategi } \\
\text { kemitraan } \\
\text { yang menjadi } \\
\text { kunci sukses }\end{array}$ & - Kerjasama dan kemitraan & - Kemitraan & $\begin{array}{l}\text { - Pesaing sebagai } \\
\text { mitra } \\
\text { - Beraliansi } \\
\text { - Komunikasi } \\
\text { informal }\end{array}$ \\
\hline
\end{tabular}

(Sumber: Axial Data Coding, 2019)

\section{Kesimpulan \& Saran \\ Kesimpulan}

Arah strategi \& kebijakan pengembangan Desa Wisata Gubugklakah adalah untuk menjadikan Desa Wisata yang dikelola secara professional yaitu menggunakan pendekatan bisnis yang melibatkan seluruh stakeholder dalam kerangka Penta-Helix, dengan tujuan akhir untuk kesejahteraan bersama.

Peran serta stakeholder yang terlibat di dalam pengembangan Desa Wisata Gubugklakah dalam konsep kemitraan strategis telah berjalan dengan baik yang ditandai dengan kekompakan yang dilandasi oleh asas saling percaya, keterbukaan, saling membutuhkan, dan saling menguntungkan.

Aspek keuangan merupakan alasan klasik yang menjadi permasalahan yang dihadapi Desa Wisata Gubugklakah. Selain itu, stigma yang negatif mengenai pariwisata bagi masyarakat Gubugklakah yang religius merupakan tantangan terbesar untuk mengembangkan desa wisata. Namun dengan berpegang pada lima konsep pengelolaan desa wisata, yakni kepemimpinan, sistem pembagian profit, inovasi produk, kemitraan, dan pemasaran melalui pendekatan personal, kekeluargaan, memberikan bukti kongkrit kepada masyarakat serta merlalui strategi kemitraan merupakan strategi ampuh dalam mewujudkan kesejahteraan masyarakat yang menjadi tujuan dibentuknya Desa Wisata Gubugklakah

\section{Saran}

Hasil penelitian ini memberikan implikasi baik secara teoretis maupun. Beberapa saran kepada tempat penelitian dan stakeholder bidang pariwisata, diantaranya:

1. Kementerian Pariwisata perlu menyediakan regulasi mengenai pengelolaan Desa Wisata yang dapat menjadi payung hukum, agar tercipta standar pengelolaan Desa Wisata yang memiliki daya saing dan tetap memperhatikan pembangungan yang berkelanjutan.

2. Ladesta disarankan untuk membuat formalitas perjanjian kerjasama dengan para mitra yang telah ada, agar tidak terjadi kesenjangan bilamana pengurus Ladesta atau mitra tersebut berganti orang. 
3. Ladesta disarankan untuk segera memiliki badan hukum (BUMDES), agar mempermudah akses permodalan dan pengembangan usaha.

4. Ladesta disarankan untuk memiliki rencana strategis mengenai strategi kemitraan yang terdokumentasi, agar dalam setiap pergantian posisi pengurus, konsistensi dan standar program-program dapat terus terjaga.

Penelitian ini telah memotret dan menggali bagaimana kemitraan strategis antar stakeholder telah mampu diterapkan dalam pengembangan desa wisata yang berkelanjutan. Namun, karena semua informasi yang digali bersumber kepada para pelaku desa wisata saja, maka penelitian selanjutnya diharapkan menggali informasi dari pihak ekaternal, dalam hal ini para mitra desa wisata, misalnya dengan pihak travel agent, hotel, dan usaha pariwisata lainnya, serta pihak akademisi yang terlibat langsung ataupun tidak langsung dengan desa wisata Gubugklakah, sehingga mendapatkan prestasi yang membanggakan

\section{Daftar Pustaka}

Arifin, Z. (2011). Implementasi Manajemen Stratejik Berbasis Kemitraan Dalam Meningkatkan Mutu SMK (Studi Pada SMK Kelompok Teknologi Bidang Otomotif di Kota Yogyakarta). Disertasi, UPI, Bandung.

Arya, Bindu \& Salk, Jane E. (2006). Cross-Sector Alliance Learning and Effectiveness of Voluntary Codes of Corporate Social Responsibility, Business Ethics Quarterly, Vol. 16(2), p. 211-234.

Calzada, Igor and Fredrik Bjork, (2013), Future of Cities Programme and Forum for Social Innovation Sweden, Oxford University, tersedia: http://www.incontextfp7.eu/sites/default/files/Bjork_POSTER_berlin_2013_1.pdf

Denzin, N. K., \& Lincoln, Y. S. (1998). Collecting and Interpreting Qualitative Material. Thousand Oaks, CA: Sage.

Googins, Bradley K., Steven A. Rochlin (2000). Creating the Partnership Society: Understanding the Rhetoric and Reality of Cross-Sectoral Partnerships, Business and Society Review, Vol. 105(1), p. $127-144$.

Hidayah, Nurdin (2019). Pemasaran Destinasi Pariwisata. Bandung: Alfabeta

Inskeep, Edward. (1991). Tourism Planning: An Integrated and Sustainable Tourism Development Approach. New York: Van Norstrand Reinhold.

Kardono, Don (2017). Kementerian Wisata Fokus Genjot Pengembangan Desa Wisata, tersedia dalam: http://www.berdesa.com/kementerian-wisata-fokus-genjotpengembangan-desa-wisata/ (diakses pada 09 Januari 2020).

Muhyi, A., Arianis C., Iwan S., Tetty H. (2017). The Penta Helix Collaboration Model in Developing Centers of Flagship Industry in Bandung City, Review of Integrative Business and Economics Research, Vol. 6(1), p.412-417.

Nano-technology, (2012), Penta Helix, tersedia dalam: http://congresses. icmab.es/ews2012/ presentations/Leif\%20Rasmussen.pdf

Neergaard, P., Thusgaard, J., \& Crone Jensen, E. (2009). Barriers and Success Factors in the Establishment and Continuous Development of NGO-Business Partherships in Denmark. Working Paper. cbsCSR. Copenhagen: Copenhagen Business School.

Noorul, Dato' Sri, (2014). Open Innovation in Public Service Reform, Putrajaya International Convention

Centre

(PICC), tersedia dalam: 
http://capam2014.mampu.gov.my/NOTES/DAY\%203/Hall\%203/Dato\%27\% 20Sri\%20Dr\%20Noorul.pdf

NYS Procurement Bulletin (1996). Strategic Partnerships Preliminary Guidelines, tersedia dalam: https://www.ogs.state.ny.us/procurecounc/pdfdoc/strateg.pdf (diakses 09 Januari 2020).

Radar Malang, (2018). H. M. Anshori Raih Penghargaan Satya Lencana, tersedia dalam: https://radarmalang.id/purnomo-h-m-ansori-ketua-pokdarwis-gubugklakah-raihpenghargaan-satya-lencana-kepariwisataan-kemenpar-2018/, (diakses pada 09 Januari 2020)

Rohmah, Nasyikhatur, dan M. Ishom. (2016). Jurnal Pendidikan Nonformal, Vol. 11(2), p. 8387.

Sugiama, A.G. (2016). Pengembangan Aset Desa Wisata Berbasis Pentahelix Model, Orasi IImiah Dies Natalis Politeknik Negeri Bandung ke 46, 2016

Suherlan, H., (2017). Strategic alliances in institutions of higher education: a case study of Bandung and Bali Institutes of Tourism in Indonesia. International Journal of Tourism Cities, 3(2), pp.158-183.

Thaib, Hiramsyah S. (2017). Desa Wisata Jadi Perhatian Utama, tersedia dalam: https://travel.kompas.com/read/2017/05/22/191500727/desa.wisata.jadi.perhatia n.utama.?page=all., (diakses pada 09 Januari 2020).

Wiendu, Nuryanti. (1993). Concept, Perspective and Challenges, makalah bagian dari Laporan Konferensi Internasional mengenai Pariwisata Budaya. Yogyakarta: Gadjah Mada University Press.

Wihasta, C.R. \& Prakoso, H.B.S., 2012. Perkembangan Desa Wisata Kembang Arum dan Dampaknya Terhadap Kondisi Sosial Ekonomi Masyarakat Donokerto Kecamatan Turi. Jurnal Bumi Indonesia, 1(1). Tersedia: https://media.neliti.com/media/publications/76191-ID-perkembangan-desawisata-kembang-arum-da.pdf

Wise, G., Retzleff, D., Reilly, K. (2005). Adapting Scholarship Reconsidered and Scholarship Assessed to Evaluate University of Wisconsin-Extension Outreach Faculty for Tenure and Promotion, Journal of Higher Education Outreach and Engagement, Volume 7(3), p. 5

Yahya, Arief (2017). Obama Bisa Promosikan Wisata Indonesia ke Wisman Amerika, tersedia dalam: $\quad$ https://www.cnnindonesia.com/gaya-hidup/20170624181538-307223987/obama-bisa-promosikan-wisata-indonesia-ke-wisman-amerika, (diakses pada 09 Januari 2020). 